\title{
The Impact of Religious Beliefs, Practices, and Social Networks on Rwandan Rescue Efforts During Genocide
}

Nicole Fox

California State University, Sacramento

Hollie Nyseth Brehm

The Ohio State University

John Gasana Gasasira

University of Rwanda

Follow this and additional works at: https://digitalcommons.usf.edu/gsp

\section{Recommended Citation}

Fox, Nicole; Nyseth Brehm, Hollie; and Gasasira, John Gasana (2021) "The Impact of Religious Beliefs, Practices, and Social Networks on Rwandan Rescue Efforts During Genocide," Genocide Studies and Prevention: An International Journal: Vol. 15: Iss. 1: 97-114.

DOI:

https://doi.org/10.5038/1911-9933.15.1.1790

Available at: https://digitalcommons.usf.edu/gsp/vol15/iss1/9

This Articles is brought to you for free and open access by the Open Access Journals at Digital Commons @ University of South Florida. It has been accepted for inclusion in Genocide Studies and Prevention: An International Journal by an authorized editor of Digital Commons @ University of South Florida. For more information, please contact digitalcommons@usf.edu. 


\section{The Impact of Religious Beliefs, Practices, and Social Networks on Rwandan Rescue Efforts During Genocide}

\section{Acknowledgements}

We would like to thank the Harry Frank Guggenheim Foundation and the Constant H. Jacquet Research Award for generous funding for this research. 


\title{
The Impact of Religious Beliefs, Practices, and Social Networks on Rwandan Rescue Efforts During Genocide
}

\author{
Nicole Fox \\ California State University, Sacramento \\ Sacramento, California, USA \\ Hollie Nyseth Brehm \\ The Ohio State University \\ Columbus, Ohio, USA \\ John Gasana Gasasira \\ University of Rwanda \\ Kigali, Rwanda
}

\section{Introduction}

When genocidal violence began in Rwanda in April of 1994, Aurore, a pregnant mother of two, stayed close to home. She heard news of killing groups targeting Tutsi throughout the country, and soon, terrified Tutsi arrived in her village to seek refuge where violence had not yet begun. When several of these individuals asked her for help, Aurore knew what she and her family had to do. Even though it was incredibly risky for Hutu to try to save Tutsi, she hid a young boy and his mother (among others) in her home and-when needed-pretended the child was her nephew. ${ }^{1}$

When asked about the rescue years later, Aurore explained: "No, I was not afraid. If I die, I will die, but people should understand that blood is blood...we should respect each other. But, I was not afraid of this." 2 Aurore began identifying as a Seventh-day Adventist when she was 15 years old, and she was convinced that her actions to rescue people were exactly what God had wanted her to do. Reflecting back, she shared: "Maybe it was God who protected those people [I rescued], along the way until they got to our house." Further, Aurore believed her collective acts with her husband and children were worth the risk of death. In her words: "We are human. I believe that if you are mortal—and every man is mortal—you may die today, but I will die tomorrow, and it is better to protect each other from this." 3

Unlike Aurore, the majority of Hutu decided not to rescue Tutsi during the genocide. Previous scholarship on rescue has emphasized the seemingly uncommon psychological characteristics of those who rescue, with many scholars arguing that they possess what has become known as an "altruistic personality." 4 Although psychological traits are undoubtedly important for explaining these prosocial behaviors, research also suggests that social factors impact the dynamics of rescue, such as who rescues and how they do so. ${ }^{5}$ This article focuses on the role of one particular social factor-religion-during rescue efforts. Specifically, we ask: how did religious beliefs, practices, and social networks shape rescue efforts during the 1994 genocide in Rwanda?

\footnotetext{
${ }^{1}$ Pseudonym, Female, Age 39 at the time of rescue, Seventh-day Adventist, 2019, Rwanda.

2 Ibid.

${ }^{3}$ Ibid.

${ }^{4}$ For example, see Samuel P. Oliner and Pearl M. Oliner, The Altruistic Personality: Rescuers of Jews in Nazi Europe (New York: The Free Press, 1992), 142; Ervin Staub, "The Psychology of Bystanders, Perpetrators, and Heroic Helpers," International Journal of Intercultural Relations 17, no. 3 (1993), 334.

5 Nicole Fox and Hollie Nyseth Brehm, "'I Decided to Save Them:' Factors that Shaped Participation in Rescue Efforts During the Genocide in Rwanda," Social Forces 96, no. 4 (2018), 1630.
}

Nicole Fox, Hollie Nyseth Brehm, and John Gasana Gasasira. "The Impact of Religious Beliefs, Practices, and Social Networks on Rwandan Rescue Efforts During Genocide." Genocide Studies and Prevention 15, no. 1, 97-114. https:// doi.org/10.5038/1911-9933.15.1.1790.

(C) 2021 Genocide Studies and Prevention. 
Relying on 45 in-depth interviews with individuals who rescued Tutsi in Rwanda, we demonstrate that religion is tied to rescue efforts in at least three ways: 1) through the creation of cognitive safety nets that enabled high-risk actions; 2) through religious practices that isolated individuals from the social networks of those committing the violence; and 3) through religious social networks where individuals encountered opportunities and accessed resources to rescue. As such, we emphasize the social dimensions of religion and thus depart from existing literature on religion and rescue, which examines the religious denominations of those who rescued as well as the stated religious justifications underpinning rescue efforts.

More broadly, the case of rescue in Rwanda provides important insights about religion and resisting violence. It illustrates how religious socialization and beliefs can support high-risk collective action, how religious practices may buffer individuals from recruitment to violent social movements, and how religious social networks and spaces can connect individuals in ways that enable them to save lives during extreme political violence. It is consequently vital to better understand the religious dynamics underpinning attempts to save persecuted individuals.

We begin by examining existing research on religion and rescue efforts. We then address literature on decision-making and high-risk behavior in order to situate how religiosity ${ }^{6}$ shapes actions and situational contexts. Next, we describe our interview data, followed by our findings on how religious practices, spaces, and social networks impacted acts of rescue in Rwanda. Broadly, we illustrate how each of these factors shaped rescue efforts, illuminating how religion mattered in previously undocumented ways.

\section{Religion and Rescue Efforts}

Studies about individuals who have engaged in rescue during genocide are often cited in a wider body of literature that seeks to understand the social and psychological characteristics of "heroes" and "moral exemplars."7 Among these characteristics, scholars have devoted significant attention to understanding the possible connection between religion and rescue. This scholarship has generally centered on two interrelated questions: 1) What are the religious denominations and the levels of religiosity among those who rescue? and 2) Did religion motivate these individuals to rescue?

Regarding the first question, some previous scholarship has suggested that individuals who adhere to minority religions may be particularly inclined to rescue due to the empathy that accompanies identification with a minority group. ${ }^{8}$ More recent work has likewise argued that individuals belonging to minority religions may be more likely to rescue, while emphasizing the collective aspects tied to their minority status. For instance, Braun ${ }^{9}$ suggests that a religious community's desire and ability to resist genocide depends on how it is situated relative to the religious majority, making minority communities more inclined to protect persecuted groups. For Braun, religious social networks are particularly important for understanding minority rescue efforts, as he argues that minority social networks are better able to recruit and retain individuals who rescue. ${ }^{10}$

\footnotetext{
${ }^{6}$ Religiosity includes religious beliefs, worldviews, convictions, practices, institutional affiliations, and rituals.

7 See Stephanie Fagin-Jones, "Holocaust Heroes: Heroic Altruism of Non-Jewish Moral Exemplars in Nazi Europe," in Handbook of Heroism and Heroic Leadership, ed. Scott T. Allison et al. (New York: Routledge, 2016), 203; Kristian Frisk, "What Makes a Hero? Theorising the Social Structuring of Heroism," Sociology 53, no. 1 (2019), 88.

8 Robert Braun, Protectors of Pluralism: Religious Minorities and the Rescue of Jews in the Low Countries during the Holocaust (Cambridge: Cambridge University Press, 2019), 16.

${ }^{9}$ Braun, Protectors of Pluralism, 216-242.

10 Ibid.
} 
However, others have frequently noted the diversity of people who rescue, based on both religious affiliation and level of religiosity. ${ }^{11}$ In one of the largest comparative studies of Christian individuals who rescued during the Holocaust and those who did not, Oliner and Oliner ${ }^{12}$ found that the majority of both groups were affiliated with religious institutions, and shared similar levels of personal and parental religiosity. This evidence suggests that religiosity and ties to religious institutions (whether majority or minority) may not strongly differentiate people who rescue from those who do not. Indeed, those who rescue are often heterogeneous in terms of religiosity, with levels ranging from non-religious to very devout. ${ }^{13}$

Researchers have also addressed religious motivations for rescue, with mixed results. In the same study referenced above, Oliner and Oliner ${ }^{14}$ found that only 15 percent of participants cited religion, God, or Christianity as significant motivators in their decisions to rescue. Varese and Yaish ${ }^{15}$ even found that the less religious respondents in their study were actually more likely to rescue. However, other studies have cited religion as a more prominent motivating factor for rescue, though this motivation is more likely among those who identify as highly religious. ${ }^{16}$

A significant number of qualitative studies also provide examples of individuals citing religion, God, or biblical teachings as motivations for their rescue efforts. ${ }^{17}$ For instance, in the case of Nazi Germany, scholars have argued that some Christians who rescued Jews did so in part because they saw them as the "chosen people of God."18 Some people who rescued during the Holocaust have also stated that general religious teachings encouraged their efforts. ${ }^{19}$ Similarly, others have cited biblical texts, which call on believers to be compassionate and assist people in need, as their inspiration to rescue. ${ }^{20}$ These studies demonstrate how some individuals tie their decision to rescue to moral religious lessons.

Taken together, existing scholarship on rescue and religion has thus generated mixed results. This body of work suggests that religious people are not necessarily more inclined to rescue than non-religious people, with some scholarship indicating that religious minorities

11 Gay Block and Malka Drucker, eds., Rescuers: Portraits of Moral Courage in the Holocaust (New York: Lynne Rienner Publishers, 1992), 6; Stephanie Fagin-Jones and Elizabeth Midlarsky, "Courageous Altruism: Personal and Situational Correlates of Rescue During the Holocaust," The Journal of Positive Psychology 2, no. 2 (2007), 138, Oliner and Oliner, The Altruistic Personality, 154.

12 Oliner and Oliner, The Altruistic Personality, 156.

13 Jessica Casiro, “Argentine Rescuers: A Study on the 'Banality of Good,'” Journal of Genocide Research 8, no. 4 (2006), 441.

14 Oliner and Oliner, The Altruistic Personality, 155.

15 Federico Varese and Meir Yaish, “The Importance of Being Asked: The Rescue of Jews in Nazi Europe," Rationality and Society 12, no. 3 (2000), 320.

16 Peal M. Oliner et al., "Very Religious and Irreligious Rescuers," in Remembering for the Future: The Holocaust in an Age of Genocide, ed. John K. Roth et al. (London: Palgrave Macmillan, 2001), 313; Michael L. Gross, "Jewish Rescue in Holland and France during the Second World War: Moral Cognition and Collective Action," Social Forces 73, no. 2 (1994), 474.

17 Eva Fleischner, "Remembrance and Responsibility: Rescuers of Jews During the Shoah," in Good and Evil After Auschwitz: Ethical Implications for Today, ed. Jack Bemporad et al. (Hoboken: KTAV Publishing House, 2000), 206; Eva Fogelman, "The Rescuer Self," in The Holocaust and History: The Known, the Unknown, the Disputed, and the Reexamined, ed. Michael Berenbaum and Abraham J. Peck (Bloomington: Indiana University Press, 1998), 674; Mitchell Hoffman, "Does Higher Income Make You More Altruistic? Evidence from the Holocaust," The Review of Economics and Statistics 93, no. 3 (2011), 880-881; Oliner and Oliner, The Altruistic Personality, 155; Nechama Tec, When Light Pierced the Darkness: Christian Rescue of Jews in Nazi-Occupied Poland (Oxford: Oxford University Press, 1986), 137.

18 David P. Gushee, "Rescuers: Their Motives and Morals," in The Holocaust and the Christian World: Reflections on the Past, Challenges for the Future, ed. Carol Rittner et al. (London: Beth Shalom Holocaust Memorial and Education Centre, 2000), 160; Oliner and Oliner, The Altruistic Personality, 154.

19 Fleischner, Remembrance and Responsibility, 206.

20 David P. Gushee, "Many Paths to Righteousness: An Assessment of Research on Why Righteous Gentiles Helped Jews," Holocaust and Genocide Studies 7, no. 3 (Winter 1993), 389. 
may be an exception, perhaps due to greater empathy or well-established, insular social networks in these communities. Scholars have also demonstrated that people who rescue cite religion, God, and biblical teachings as motivating factors in a relatively small percentage of cases but that such motivations may be particularly strong among the highly religious.

However, researchers have yet to assess other dimensions of religion-beyond denomination, level of religiosity, and motivation-which may impact rescue efforts. Consequently, we sought to understand how religious beliefs, practices, and social networks may impact rescue, specifically, exploring how religious beliefs may enable particularly high-risk rescue actions. ${ }^{21}$ We likewise address how religious practices may insulate those who rescue from mobilization to violence. Finally, we analyze how religious social networks-apart from minority social networks-shape rescue efforts, including who gets rescued, where they are rescued, and how rescues takes place. To inform our inquiry, we looked beyond existing literature on religion and rescue to ascertain how religion shapes action in broader social circumstances with an emphasis on religion, decision-making, and high-risk action.

\section{Religion, Decision-making, and High-Risk Action}

Scholars have long tied religious beliefs to decision-making. For instance, scholars have found that religion influences a variety of life decisions, ${ }^{22}$ including choices relating to family size, ${ }^{23}$ occupation, ${ }^{24}$ education, ${ }^{25}$ and voting. ${ }^{26}$ Important for this study, much previous research has addressed how religion impacts helping and prosocial behaviors, such as volunteerism and charitable giving. ${ }^{27}$ Such studies on religion and decision-making have analyzed a range of behaviors, from low-risk, everyday practices to high-stakes action.

Particularly relevant to high-stakes action like rescue, a subset of scholarship on religion seeks to understand how religious beliefs shape peoples' perceptions of and feelings about death, shedding light on why some religious individuals may take life-threatening risks. To be clear, such beliefs are not the motivating factors behind taking such risks but may instead inform peoples' decision-making processes. Specifically, scholars have argued that religious convictions reduce some fears about death, ${ }^{28}$ which can help explain religious individuals'

21 While a motivation consists of a primary reason or justification driving an action (often realized or narrated in the aftermath), a belief is a broader conviction that may also impact action, though often in less linear ways.

22 Emily Sigalow et al., "Religion and Decisions About Marriage, Residence, Occupation, and Children," Journal for the Scientific Study of Religion 51, no. 2 (2012), 318-321.

23 Jennifer B. Barrett et al., "Religion and Attitudes Toward Family Planning Issues Among US Adults," Review of Religious Research 56, no. 2 (2014), 184.

24 Esperanza F. Hernandez et al., "Hearing the Call: A Phenomenological Study of Religion in Career Choice," Journal of Career Development 38, no. 1 (2011), 70; Madonna G. Constantine et al., "Religion, Spirituality, and Career Development in African American College Students: A Qualitative Inquiry," The Career Development Quarterly 54, no. 3 (2011), 233.

25 Scott Schieman, "Education and the Importance of Religion in Decision Making: Do Other Dimensions of Religiousness Matter?" Journal for the Scientific Study of Religion 50, no. 3 (2011), 583.

${ }^{26}$ Chris, J. Fastnow et al., "Holy Roll Calls: Religious Tradition and Voting Behavior in the U.S. House," Social Science Quarterly 80, no. 4 (December 1999), 694.

27 See Patty Van Cappellen et al., "Religiosity and Prosocial Behavior Among Churchgoers: Exploring Underlying Mechanisms," The International Journal for the Psychology of Religion 26, no. 1 (2016), 24-28; Christopher J. Einolf, "The Link Between Religion and Helping Others: The Role of Values, Ideas, and Language," Sociology of Religion 72, no. 4 (2011), 442; Jerry Z. Park and Christian Smith, “'To Whom Much Has Been Given...:' Religious Capital and Community Voluntarism among Churchgoing Protestants," Journal for the Scientific Study of Religion 39, no. 3 (2000), 283; Isabelle Pichon and Vassilis Saroglou, "Religion and Helping: Impact of Target Thinking Styles and Just-World Beliefs," Psychology of Religion 31, no. 2 (2009), 232.

28 L. D. Nelson and C. H. Cantrell, "Religiosity and Death Anxiety: A Multi-Dimensional Analysis," Review of Religious Research 21, no. 2 (1980), 154; Stephen R. Harding et al., "The Influence of Religion on Death Anxiety and Death Acceptance," Mental Health, Religion E Culture 8, no. 4 (2005), 256; Nava Silton et al., "The Association Between Religious Beliefs and Practices and End-of-Life Fears Among Members of the Presbyterian Church (U.S.A.)," Review of Religious Research 53, no. 1 (2011), 366. 
decisions to participate in high-risk action. For instance, Harding and colleagues ${ }^{29}$ found that parishioners who had high theological religiosity-meaning they had a strong belief in God's existence and in an afterlife-also had low death anxiety. In turn, when individuals hold religious beliefs that facilitate low death anxiety, they may take extraordinary risks aligning with their religious convictions, as their beliefs may minimize the perceived consequences of high-risk actions.

Some of this scholarly work also addresses how religious beliefs influence individuals' decisions not to engage in high-risk actions, particularly those actions religious teachings label as deviant or wrong. For instance, researchers have argued that religious beliefs often deter drug and alcohol use, ${ }^{30}$ gambling, ${ }^{31}$ cheating behavior, ${ }^{32}$ and crime. ${ }^{33}$ Important to this study, religiosity at the macro and meso levels-such as the rates of religious adherence and the civic engagement of religious adherents-can shape the frequency and intensity of racial violence. ${ }^{34}$ Further, community-level religiosity has been found to impact rates of violent crime and youth delinquency. ${ }^{35}$ Specifically, religious institutions significantly buffer "...the effects of neighborhood disorder on crime and, in particular, serious crime." 36

Observing these relationships, scholars have thus sought to theorize possible underlying mechanisms mediating the relationship between religion and high-risk behavior. In some cases, such deterrence from high-risk behavior can be explained by Durkheim's "moral community thesis," 37 which proposes that a group's level of religiosity impacts the behaviors of individual group members. Adherence to religious beliefs, as well as ties within social networks, can deter individuals from behaviors condemned by religious scripture and social networks adhering to the scripture. For instance, studies have shown that lower rates of HIV risk behavior, such as engaging in pre-marital and extra-marital sex, can be partially explained by religious community membership and indoctrination across dominations. ${ }^{38}$

${ }^{29}$ Harding et al., The Influence of Religion, 256.

30 Ira Wasserman and Frank Trovato, "The Influence of Religion on Smoking and Alcohol Consumption: Alberta Case Study," International Review of Modern Sociology 26, no. 2 (1996), 49.

31 Christopher G. Ellison and Michael J. McFarland, "Religion and Gambling Among U.S. Adults: Exploring the Role of Traditions, Beliefs, Practices, and Networks," Journal for the Scientific Study of Religion 50, no. 1 (2011), 96; David Eitle, "Religion and Gambling Among Young Adults in the United States: Moral Communities and the Deterrence Hypothesis," Journal for the Scientific Study of Religion 50, no. 1 (2011), 76.

32 Azim F. Shariff and Ara Norenzayan, "Mean Gods Make Good People: Different Views of God Predict Cheating Behavior," The International Journal for the Psychology of Religion 21, no. 2 (2011), 92. Note that this study is about cheating behavior such as dishonesty on a test rather than infidelity.

33 Colin J. Baier and Bradly R. E. Wright, “'If You Love Me, Keep My Commandments:' A Meta-Analysis of the Effect of Religion on Crime," Journal of Research in Crime and Delinquency 38, no. 1 (2001), 13; Thorleif Pettersson, "Religion and Criminality: Structural Relationships Between Church Involvement and Crime Rates in Contemporary Sweden," Journal for the Scientific Study of Religion 30, no. 3 (1991), 288.

34 Jeffery T. Ulmer and Casey T. Harris, "Race and the Religious Contexts of Violence: Linking Religion and White, Black, and Latino Violent Crime," Sociological Quarterly 54, no. 4 (2013), 610-646. Ulmer and Harris found that different religious contexts matter in reducing violence for black, Latino, and white communities. See Ulmer and Harris, Religious Contexts of Violence, 613.

35 John J. Dilulio, Jr., "More Religion, Less Crime? Science, Felonies, and the Three Faith Factors," Annual Review of Law and Social Science 5, no. 1 (2009), 128; Byron R. Johnson et al., "Does Adolescent Religious Commitment Matter?: A Reexamination of the Effects of Religiosity on Delinquency," Journal of Research in Crime and Delinquency 38, no. 1 (2001), 37

36 Byron Johnson et al., “The 'Invisible Institution' and Black Youth Crime: The Church as an Agency of Local Social Control," Journal of Youth and Adolescence 29 (2000), 490.

37 Emile Durkheim, Suicide (New York: Free Press, [1897] 1966), 159-160.

38 Robert C. Garner, "Safe Sects? Dynamic Religion and AIDS in South Africa," The Journal of Modern African Studies 38, no. 1 (2000), 64 . 
Beyond explaining deterrence from high-risk behaviors, religious social networks can also help explain participation in collective action and social movements in general. ${ }^{39}$ Such lowrisk collective action, centering on religious identity and partnership across religious institutions, is illustrated by the recent "Save Darfur Coalition" - which advocated for U.S. intervention in Sudan. ${ }^{40}$ In another example, Catholic women who spearheaded the movement for New York's welfare state at the turn of the 20th century drew on their Catholic social networks to mobilize state resources for the poor. ${ }^{41}$ Likewise, US civil rights activists participating in the 1964 Freedom Summer mobilized with civil rights activists in the North, including white Jews, to participate in Southern voter registration drives, with many sacrificing their personal safety and, for some, their lives. ${ }^{42}$ As these examples illustrate, various religious movements throughout history have utilized their social networks to mobilize collective action of various risk levels, often championing their religious values.

Given this literature on religion, decision-making, and high-risk action, we address how religious beliefs, practices, and social networks impact rescue. Again, we do so because existing literature on religion and rescue has mostly examined religious adherence and religious motivations, rather than these other social factors. Here, we expand to address other mechanisms through which religion may impact rescue via a case study of rescue in Rwanda.

\section{Case Background and Methods}

Religion and Rescue Efforts in Rwanda

On April 6, 1994, unknown assailants shot down Rwandan President Juvénal Habyarimana's airplane. His assassination followed decades of tension between Rwanda's two main ethnic groups, the Hutu and the Tutsi, culminating in civil war, economic recession, and volatile social unrest. Targeted killings began a few hours after the plane crash, and radio broadcasters and local leaders urged all Hutu to kill Tutsi. Many answered these calls inciting violence, including army officials, political leaders, and thousands of civilians. ${ }^{43}$ Several months later, up to one million Tutsi and moderate Hutu were dead, and millions were displaced.

When the genocide began, Rwanda was one of the most Christian countries in Africa. Approximately 90 percent of Rwandans were members of Catholic or Protestant churches, and most families attended religious services on a regular basis. ${ }^{44}$ Yet, religious institutions had a complicated relationship with the violence. Well before 1994, churches were engaged in ethnic politics and discrimination, and some priests wrote histories to help justify ethnic exclusion. ${ }^{45}$

39 Elizabeth D. Hutchinson, "Spirituality, Religion, and Progressive Social Movements: Resources and Motivation for Social Change," Journal of Religion \& Spirituality in Social Work: Social Thought 31, no. 1-2 (2012), 106; Paul Lichterman, "Religion in Public Action: From Actors to Settings," Sociological Theory 30, no. 1 (2012), 17; Doug McAdam, "Recruitment to High-Risk Activism: The Case of Freedom Summer," American Journal of Sociology 92, no. 1 (1986), 78.

40 Jodi Eichler-Levine and Rosemary Hicks, "As Americans against Genocide: The Crisis in Darfur and Interreligious Political Activism," American Quarterly 59, no. 3 (2007), 712.

${ }^{11}$ Maureen Fitzgerald, Habits of Compassion: Irish Catholic Nuns and the Origins of New York's Welfare System, 1830-1920 (Champaign: University of Illinois Press, 2006), 81.

42 Debra Schultz, Going South: Jewish Women in the Civil Rights Movement (New York: New York University Press, 2001), 57.

${ }^{43}$ See Alison Des Forges, Leave None to Tell the Story: Genocide in Rwanda (New York: Human Rights Watch, 1999), 10, accessed April 20, 2021, https:/ / www.hrw.org/sites/default/files/media 2020/12/rwanda-leave-none-to-tell-thestory.pdf; Mahmood Mamdani, When Victims Become Killers: Colonialism, Nativism, and the Genocide in Rwanda (Princeton: Princeton University Press, 2001), 209; Scott Straus, The Order of Genocide: Race, Power, and War in Rwanda (Ithaca: Cornell University Press, 2006), 29; Lee Ann Fujii, Killing of Neighbors: Webs of Violence in Rwanda (Ithaca: Cornell University Press, 2009), 55; André Guichaoua, From War to Genocide: Criminal Politics in Rwanda, 1990-1994 (Madison: University of Wisconsin Press, 2015), 220.

${ }_{44}$ Timothy Longman, "Church Politics and the Genocide in Rwanda," Journal of Religion in Africa 31, no. 2 (2001), 164.

45 Timothy Longman, Christianity and Genocide in Rwanda (Cambridge: Cambridge University Press, 2009), 162. 
During the genocide itself, much of the killing occurred in churches, where Tutsi civilians sought refuge. 46

While some priests and other religious leaders engaged in violence, other individuals tried to stop the violence and save others. ${ }^{47}$ Here, we focus on how religion shaped such rescue attempts. In doing so, we follow Burnet's definition of individuals involved in rescue efforts as "...those who protected or evacuated Tutsi, or made other efforts to save them and who did not participate in the genocide whether by killing, raping, destroying property, or looting...They required not only the impulse to help but also the persistence to make the decision both to rescue and not to participate [in the genocide] repeatedly over time." 48 To be clear, scholars have documented that people engage in dynamic actions during genocide, with some individuals killing on certain days and rescuing on others. ${ }^{49}$ Nevertheless, we restrict our analyses to those who rescued, but who did not kill, in order to leverage the connection between religion and rescue. By having a sample of solely those who rescued, we can better identify how religion impacted rescue rather than how killing and religion may have affected rescue, which would be difficult to disentangle. 50

\section{Our Sample and In-Depth Interviews}

We rely upon 45 in-depth interviews with people who participated in rescue efforts in Rwanda between April-July 1994. Working with translators, the first two authors conducted most of these interviews over several fieldwork trips between 2012 and 2019.51 Three Rwandans, including the third author, also conducted interviews, as further explained below.

We identified interviewees through Ibuka, a nongovernmental organization that provides services to genocide survivors throughout the country. Specifically, Ibuka recorded the testimonies of people who rescued as part of a 2009 research project. Ibuka researchers randomly selected two sectors (small regions) within each of the country's 30 districts. They then chose the two cells (a smaller geographic unit) with the largest populations of genocide survivors and the two cells with the smallest populations of survivors within these sectors. In each of the cells, Ibuka researchers worked with researchers from the National University of Rwanda to conduct focus groups with survivors, people who committed violence, community leaders, judges in the post-genocide court system (i.e., gacaca), teachers, religious officials, and others. The main goal of the focus groups was to create lists of people who rescued. The researchers then vetted all individuals whose names appeared on the lists, ensuring both that they rescued and that they did not participate in the genocide by talking with other community members and, if possible, the people they rescued.

We obtained Ibuka's cumulative list of 273 vetted individuals who rescued and worked through local Ibuka representatives to secure their contact information. We then contacted people on the list and asked if they would be willing to participate in an interview on their rescue experience. We began by contacting people close to a central location (Kigali, Rwanda's capital). We also called potential respondents in each of Rwanda's five provinces, resulting in

46 Des Forges, Leave None, 161.

47 Daniel Rothbart and Jessica Cooley, "Hutus Aiding Tutsis during the Rwandan Genocide: Motives, Meanings, and Morals," Genocide Studies and Prevention: An International Journal 10, no. 2 (2016), 77.

48 Jennie E. Burnet, "Accountability for Mass Death, Acts of Rescue, and Silence in Rwanda," in A Companion to the Anthropology of Death, ed. Antonius C. G. M. Robben (Hoboken: John Wiley \& Sons, Inc, 2018), 207.

${ }^{49}$ Fujii, Killing of Neighbors, 585-588; Aliza Luft, "Toward a Dynamic Theory of Action at the Micro Level of Genocide: Killing, Desistance, and Saving in 1994 Rwanda," Sociological Theory 33, no. 2 (2015), 164.

50 For instance, below we address trust tied to religious networks-trust that was likely tarnished for people who were known for participating in the killings.

51 The research for this project was conducted in an ethical and responsible manner and complied with Institutional Review Boards (IRB) standards and protocols through a partnership with the first and second author's respective universities. The authors also received permission from the Government of Rwanda, who granted them a research permit to conduct interviews throughout the country via sponsorship by the National Commission for the Fight Against Genocide. 
interviews across the country. Specifically, respondents resided (both in 1994 and at the time of the interview) in the present-day districts of Bugesera, Gasabo, Gisagara, Karongi, Kicukiro, Muhanga, Musanze, Nyamagabe, Nyanza, and Ruhango-totaling one-third of the districts of Rwanda. No individual we asked declined to be interviewed, but several individuals on Ibuka's list had since passed away or moved.

Thirty-two of the 45 respondents were men, while 13 ( 29 percent) were women. Though we cannot speak to the broader gender distribution of people who rescued, 18.6 percent of those in the full Ibuka dataset were women.52 Furthermore, the average age of people interviewed was approximately 35 at the time of the genocide, aligning with the average age of 40 in the full Ibuka dataset. 31 of the 45 respondents were farmers at the time of the genocide, and others worked as traders, soldiers, mechanics, local leaders, nurses, traders, or business people. Notably, three respondents were religious leaders (pastors or priests). Finally, 20 were Catholic, 11 were Seventh-day Adventists, eight were Pentecostal, four were Protestant, and two were Muslim at the time of the rescue. .53

We offered to conduct interviews wherever respondents chose, which in most cases was at their homes. Respondents used the language they felt most comfortable with during interviews-including English, Kinyarwanda, French, or a combination. The first two authors worked with a translator when interviewing respondents who preferred Kinyarwanda. The third author and two other Rwandan research assistants conducted other interviews directly in Kinyarwanda, and the third author also served as a translator. We compared the transcripts of interviews conducted by American and Rwandan interviewers and found no significant differences relevant to the findings presented in this article. However, we recognize that some participants may have decided to share, or not share, certain aspects of their rescue story or religious identity depending on who they were speaking to (Rwandan interviewer vs. American interviewer), given the current political climate in Rwanda in which the government significantly constrains both research and speech. ${ }^{54}$

Interviews lasted between one to three hours and followed a semi-structured format. We asked respondents about the people they rescued, the situational context of their rescue efforts, and their reasons for rescuing. We also asked targeted questions about respondents' religiosity and the role religion played in their rescue efforts. However, respondents often also referenced religion spontaneously in their answers to questions unrelated to religion.

Upon transcription of interviews, we analyzed the transcripts using Atlas.ti, a computer software program that facilitates the organization of quotes by codes created by the users. We use pseudonyms in all quotations to protect respondents' identities, modifying quotations only slightly to correct grammatical errors. We did not alter the meaning of any responses with our minor edits.

Finally, a reader familiar with the Rwandan case may be concerned about the research climate in the country and its impact on the present study. Other scholars have written about

52 This does not necessarily indicate that women were less likely to rescue, as Ibuka researchers only interviewed the heads of households that rescued. We realized this part-way through data collection and then began interviewing both the head of household and their spouse (if they both participated in the rescue efforts).

53 According to the 1991 Census, approximately 63 percent of the country was Catholic, followed by 19 percent Protestant (including Pentecostal), 9 percent Seventh-day Adventist, 7 percent no religion, and 1 percent Muslim. Minnesota Population Center, Integrated Public Use Microdata Series, International: Version 7.2 [dataset]. (Minneapolis, MN: IPUMS, 2019), accessed April 20, 2021, https://doi.org/10.18128/D020.V7.2.

54 For exploration on the challenges of conducting fieldwork in Rwanda see Larissa R. Begley, "The Other Side of Fieldwork: Experiences and Challenges of Conducting Research in the border area of Rwanda/Eastern Congo," Anthropology Matters 11, no. 2 (2009), 1-11; Erin Jessee, "Conducting Fieldwork in Rwanda," Canadian Journal of Development Studies 33, no. 2 (2012), 266-274; Bert Ingelaere, “Learning 'To Be' Kinyarwanda in Postgenocide Rwanda: Immersion, Iteration, and Reflexivity in Times of Transition," Canadian Journal of Law and Society 30, no. 2 (2015), 277-292. 
state control regarding the narratives of the genocide. 55 However, as our interviews focused on narratives the state generally frames as heroic, fear did not seem to be pervasive amongst respondents. We also spent considerable time developing rapport with respondents before conducting interviews, and we took care to clarify that we were not working with Ibuka and that Ibuka would not learn who did or did not participate. Further, the two non-Rwandan interviewers had spent years in the country during previous fieldwork trips, enabling them to better understand the cultural nuances and norms apparent in interviews.

\section{Findings: How Religion Shapes Dynamics of Rescue}

Our analysis revealed that religion influenced several factors that in turn shaped rescue efforts among Rwandans. Specifically, we identify: 1) religious beliefs that produced cognitive safety nets enabling high-risk action, 2) religious practices that created a social buffer shielding individuals from the targeted recruitment of killing groups, and 3) religious social networks that led to and assisted in rescue efforts. In sum, cognitive safety nets impacted decisions to rescue, while social buffers afforded people (specifically men, as we address below) the space and opportunity to rescue successfully. Finally, religious social networks impacted where rescue took place, how rescue was enacted, and who was rescued.

\section{Religious Beliefs as a Cognitive Safety Net for High-Risk Action}

Most of the people we interviewed described facing the possibility of death while engaging in rescue efforts. Killing groups often threatened respondents with death or injury, and some participants witnessed the death of friends and family members. For instance, a killing group cut off the leg and finger of one man we interviewed, while another killing group slaughtered a participant's livestock. Yet, despite these high personal risks, respondents repeatedly told us that they were not deterred from rescuing - a phenomenon they linked to religious beliefs.

Claude, who saved several older adults when he was only 22 years old, explained: "My concern was about helping people. I was very religious, and I was only committed to rescuing people...I was worried, I thought death was coming. But I was bold and waited for it." 56 Christine, a devout Catholic who saved four young children, also told us how she remained staunch in her efforts to rescue, even when her life was in danger: "I was committed; I could die with them. I was not better than them. I put everything in God's hands." ${ }^{77}$ Likewise, Ahmed, a Muslim who saved four people from his mosque by covering them in a ditch in his backyard, echoed Christine's perspective by saying, "I was scared that rescuing could put me in danger, but I placed everything in God's hands. God is able to do everything." 58

Many others told us similar stories. For instance, Marie, who saved an infant girl, was threatened by people who tried to purchase and kill the Tutsi baby she was taking care of. Marie explained that her faith in God gave her the strength to refuse, noting, "God gave me this child, so I cannot sell her." 59 Alodie, who saved 11 people days after the genocide began, similarly told us:

Getting killed while saving them was not a concern to me. They [Tutsi] also had life and wanted to live like any of us. We were not special, and at the end of the day all of us will die. Therefore, it is better dying while saving life. The Bible also

\footnotetext{
55 Andrea Purdeková, “'Even If I Am Not Here, There Are So Many Eyes:' Surveillance and State Reach in Rwanda," The Journal of Modern African Studies 49, no. 3 (2011), 479; Susan Thomson, Whispering Truth to Power: Everyday Resistance to Reconciliation in Postgenocide Rwanda (Madison: University of Wisconsin Press, 2013), 13.

56 Pseudonym, Male, Age 22 at the time of rescue, Seventh-day Adventist, 2016, Rwanda.

57 Pseudonym, Female, Age 39 at the time of rescue, Catholic, 2016, Rwanda.

58 Pseudonym, Male, Age 34 at the time of rescue, Muslim, 2019, Rwanda.

59 Pseudonym, Female, Age 42 at the time of rescue, Seventh-day Adventist, 2012, Rwanda.
} 
says that lucky are those who die for Christ. If I will die, then dying saving life is honorable. 60

Gatera also felt able to risk his life for rescue, sharing that, "[p]eople used to say that I am fearless...I know that if God wants you to live and when your time to die is up, you die. Therefore, I had nothing to fear." 61 Likewise, Damascene, a pastor who hid over 300 people in his backyard church explained: "When it reached the end, I was confident that what I was doing was right. I was even sure that if I died, I would die doing the right thing." 62 Damascene also believed he had a better place awaiting him, noting, "I knew I would go to Heaven." 63

Thus, these respondents and many others attributed the strength they felt when their lives were at risk to their knowledge that God would protect them. For instance, the teachings of the Koran provided a cognitive safety net for Bashir, who attempted to save four women and three children while also working as a medical practitioner during the genocide. Bashir explained how the promise of an afterlife made him feel safe in his decision to take high risks:

In the Koran, there is a verse which says that when you kill one person, you have killed the entire world...killing that one person is like killing the entire world...saving one person is saving every person that will descend from that person...respecting what the Koran says is a blessing, and God cannot abandon you if you are doing well. Even if he does, he pays in life after death. ${ }^{64}$

Echoing this notion, William, a Pentecostal who with his parents rescued approximately 100 people, shared that, "[p]eople make different choices whereby they take different routes. Some take the right and others take the wrong route. If you believe in God, you even believe in doing good things. I was confident that God was on our side and even if it meant dying, I was ready to die." 65 Murenzi's confidence in God's protection also enabled his actions. He explained, "I did not feel scared; my hope was that whenever you do something good after praying to God, nothing wrong can happen to you." 66 Matilda, a Catholic who saved a young girl, expressed: "I became bold whenever I heard that killers were approaching. I was determined not to abandon her because I knew God could not let such an innocent child get killed...God was on our side." 67

Those who rescued reported that in their near-death experiences, they knew God would protect them, either preventing them from death or securing their afterlives. In other words, their religious beliefs enabled respondents to experience very low death anxiety in situations where it would be reasonable to experience high death anxiety. As such, religious beliefs in God's protection and in an afterlife provided those who rescued with a cognitive safety net that facilitated their high-risk actions. Religious respondents, who believed risking one's life to save another was part of God's plan or doing right by God, consequently perceived rescue efforts as lower risk, believing they would be rewarded for either successfully saving a life or dying trying and going to the afterlife.

\footnotetext{
${ }^{60}$ Pseudonym, Female, Age 50 at the time of rescue, Catholic, 2019, Rwanda.

61 Pseudonym, Male, Age 43 at the time of rescue, Protestant, 2019, Rwanda.

62 Pseudonym, Male, Age 38 at the time of rescue, Pentecostal, 2012, Rwanda.

${ }^{63}$ Ibid.

64 Pseudonym, Male, Age 24 at the time of rescue, Muslim, 2019, Rwanda.

65 Pseudonym, Male, Age 24 at the time of rescue, Pentecostal, 2019, Rwanda.

66 Pseudonym, Male, Age 41 at the time of rescue, Catholic, 2019, Rwanda.

67 Pseudonym, Female, Age 31 at the time of rescue, Catholic, 2016, Rwanda.
} 
Religious Practices as a Social Buffer against Recruitment and Discovery

Religious practices also shaped rescue efforts by providing a social buffer. By social buffer, we mean practices that insulate a person socially from particular social groups or social situations. Specifically, religious practices tied to abstaining from drinking alcohol or immoral behaviors helped keep people from being recruited to participate in genocidal violence and from being discovered by killing groups. Notably, however, we find such social practices were only a social buffer for men, which we address below and in our discussion.

To prepare and recruit for killing sprees, those committing the violence often gathered to consume alcohol. ${ }^{68}$ Consequently, individuals who were known non-drinkers due to religious convictions were often insulated from some of the most common recruitment methods. As Pascal, a Seventh-day Adventist who rescued a family of five, explained: "We were not supposed to eat meat, use sugar, take beers, and many other things. This helped me to distance myself from all people who did that." 69 Augustine, another Seventh-day Adventist who rescued several families, including his neighbor's children, similarly explained: "There are people who join religions when they are not converted. For us, we were. We were true Christians. I have never taken alcohol in my life."70 Neither men were recruited for participation in the genocidal violence.

Pascal, Augustine, and others who did not drink alcohol may have avoided recruitment to killing groups because they were not in the bars where recruitment took place. They were also likely able to avoid targeted recruitment in other settings since killing group members assumed they would refuse to drink-a prerequisite in some killing groups for new recruits. ${ }^{71}$ Pascal and Augustine thus highlight how religious practices-especially pertaining to alcohol use among Seventh-day Adventists, Muslims, and others who abstained from drinkingcreated a social buffer from others who killed. In turn, this social buffer provides insight into the circumstances surrounding rescue.

While abstinence from alcohol did not necessarily impact the decision to rescue, it likely affected the ability to rescue and the probability of successful rescue. Because Pascal and Augustine were not heavily recruited to participate in the genocide, they did not have to openly defy those who were recruiting for killing groups. This lack of confrontation may have bought them time and space from killing groups, who would search the homes of those who refused to participate in the violence. In this sense, their religious social practices likely impacted the assumptions members of killing groups made.

While religious minorities at the time of the genocide (specifically Muslims and Seventh- day Adventists) possessed a social buffer due to their abstinence from alcohol, some members of the religious majority (Catholics) also experienced a degree of insulation due to their general religious practices and typical abstention from perceived immoral behavior. Charles, a Catholic who worked with his family to save a mother and child, shared:

I rarely interacted with such people [perpetrators] because I was working at the Catholic priest's canteen. I could not get time to interact with such guys...I kept moving coming from church, coming home to gather information on where people at home were safe, going back to church, helping people at church, cooking food, serving them with food. Those killers would just tell me that I could also be killed one day, because I helped those people that were being targeted, but no one approached me telling me to join the killing...they thought we were fools because we are not interested in looting, killing people and

\footnotetext{
68 Des Forges, Leave None, 188.

${ }^{69}$ Pseudonym, Male, Age 45 at the time of rescue, Seventh-day Adventist, 2016, Rwanda.

70 Pseudonym, Male, Age 39 at the time of rescue, Seventh-day Adventist, 2016, Rwanda.

${ }^{71}$ Straus, The Order of Genocide, 149, 264.
} 
taking their property...no one approached me to mobilize me to participate in killing. ${ }^{72}$

Like Charles, people knew Chase as a very religious man, and he believed this reputation kept some people from trying to recruit him. In his words:

[Perpetrators] kept on coming, but again, they thought we are Christians, and that is why we are not participating in the killing. I remember they communicated to us that, '[i]f you are caught hiding someone, your family will also get killed, and you will also get killed. You will be ordered to kill that person, and then you will also get killed.' But, I even met the burgomaster [commune leader], and I told him, you are suspecting that we are hiding people. We do not have anyone in our house, come and search it...but they thought we are Christians...They could say: 'They are fools, do not care about them, they are Christians. That is why they are not participating.' The trust that people had in us helped. They never thought that we were hiding people in our houses. ${ }^{73}$

Thus, because Charles's family was considered to be particularly pious, people engaging in violence believed him when he said that he was not hiding people since they considered him to be too religious to lie. Because lying, killing, and stealing were deemed sins, those who knew Charles believed he could not participate in either and, for the most part, left him alone when genocidal violence swept through his village, ultimately enabling him to save the lives of six people.

Noticeably, the respondents who discussed religion as a social buffer were either religious minorities (Muslims or Seventh-day Adventists) or highly-religious Catholics, and all of them were men. No women in our sample discussed religion as a social buffer, but women also seldom mentioned being recruited to participate in the violence. In fact, killing groups rarely recruited women given that killing transgressed gendered norms, ${ }^{74}$ nor would it have been typical for women to leave their families to drink in bars. For women in this study, gender norms, roles, and socialization likely served as non-religious social buffers, affording women protection from recruitment in ways that allowed for a range of socially-acceptable and plausible excuses to not participate in the violence, given their roles as wives, mothers, or expectant mothers. Religious practices thus functioned as a social buffer largely for men.

\section{Religious Social Networks Providing Opportunities and Resources}

Religious social networks also influenced rescue efforts in significant ways. Specifically, religious social networks impacted rescue by shaping where rescue took place (e.g., among congregations and in their homes), how rescue was enacted (e.g., through religious community resources), and who was rescued (e.g., fellow church or mosque members).

Often, religious social networks facilitated the acquisition of or access to necessary resources. For instance, church members sometimes used religious spaces for rescue efforts. Gloria hid Tutsi in her local church. She explained: "I also had other people that I hid at the church; they were one child and a maid... Then two other women... also came. They had many wounds; they were cut from machetes around their faces. I put all of them in the church."75

\footnotetext{
72 Pseudonym, Male, Age 25 at the time of rescue, Catholic, 2019, Rwanda. Emphasis added.

73 Pseudonym, Male, Age 39 at the time of rescue, Seventh-day Adventist, 2019, Rwanda.

74 Des Forges, Leave None, 11, 14; Straus, The Order of Genocide, 143.

75 Pseudonym, Female, Age 30 at the time of rescue, Catholic, 2016, Rwanda.
} 
Thus, while churches were a common site for massacres, ${ }^{76}$ many acts of rescue also took place in religious spaces. Damascene, ${ }^{77}$ a pastor, hid people in the church located in his backyard. Bashir ${ }^{78}$ rescued Muslims from his religious community by hiding them in the local mosque. Echoing these patterns, Mutabazi, a Seventh-day Adventist, explained rescue efforts facilitated by religious social networks: "We agreed as a church to organize and come to church for their [Tutsi's] safety when attacks began...People ... brought them to the church...church leaders could always come to check on us and support us morally and by providing food."79

Similarly, John used church resources to undertake rescue efforts. As a pastor of a large congregation, John was able to hide hundreds of people in his church, as well as inside the deep holes used as toilets on the church property. Militias repeatedly threatened him as he performed these rescues. However, he continued helping others with the assistance of his family and fellow church members, ultimately saving over 300 lives. ${ }^{80}$ Notably, John and Damascene, both pastors, felt the most at ease using church spaces for rescue, likely due to their position as religious leaders. Yet, as Gloria, Bashir, and Mutabazi illustrate, one did not need to be a religious leader to effectively use religious spaces to hide others.

Respondents' reliance on fellow church members illustrates another mechanism through which religious social networks aided, and in some instances likely increased the success of, rescue efforts. Specifically, religious communities provided a network of helpers to assist with rescue endeavors. Forms of assistance included warning when militias were nearby, providing food, water, or shelter, or moving Tutsi from house-to-house in order to avoid discovery.

For instance, those who rescued described knowing which congregants they could call upon for help while rescuing. Seth recalled calling on a fellow congregant, explaining: "He was also a Seventh-day Adventist. I called him and asked if two of those children [whom Seth was rescuing] could go to his house... He took the two." 81 Gloria asked a woman from her church to assist her, when she was worried that she was going to be discovered rescuing a little boy. In her words: "I had requested a woman from my church to take him to her home for protection." 82 In this case and others, the success of rescues was at least partially attributed to the religious social networks of those who coordinated their actions to collectively save others.

For Eugene, his religious social network even helped save his own life. Eugene was rescuing three young girls and a young man when militias burst into his house. They threatened to kill the people he was protecting, and when Eugene intervened, a member of the militia cut off his leg and left him to bleed to death. Although he was in tremendous pain, Eugene remembered a church night watchman whom he trusted. He sent one of the young girls to the watchman to buy medicine that saved his life. Knowing that they could rely on their religious communities to help them if they were threatened or hurt likely made it easier for people like Eugene to engage in high-risk rescue efforts..$^{83}$

Finally, many respondents explained that the people they rescued were part of their religious social networks, indicating that pre-existing religious ties shaped rescue. For instance, Gloria shared that the people she rescued were from her religious community: "We shared the same religious denomination. We prayed together ... We could exchange invitations for different ceremonies." 84 Pascal also saved people from his church, explaining: "We belonged to the same

\footnotetext{
76 Longman, Christianity and Genocide, 269.

77 Interviewee first cited in note 68.

78 Interviewee first cited in note 70.

79 Pseudonym, Male, Age 42 at the time of rescue, Seventh-day Adventist, 2019, Rwanda.

80 Pseudonym, Male, Age 37 at the time of rescue, Protestant, 2012, Rwanda.

81 Pseudonym, Male, Age 30 at the time of the rescue, Seventh-day Adventist, 2016, Rwanda.

82 Interviewee first cited in note 75 .

83 Pseudonym, Male, Age 42 at the time of rescue, Catholic, 2012, Rwanda.

84 Interviewee first cited in note 75 .
} 
church. We were friends and shared everything." 85 Dido hid people he knew from the church he had been attending since he was a child, including the head choir leader, a pastor, and child parishioners whom he called his "brothers in Christ." 86 Charles and his family hid a woman and a child they knew through church, while Ahmed hid people he knew from the local mosque. Social networks, and specifically religious social networks, were consequently important for shaping several aspects of rescue during the genocide.

\section{Discussion and Conclusion}

While prior studies have focused on the religious denominations and motivations of those who rescue during genocide, we have illustrated additional pathways through which religion shapes rescue efforts. Specifically, we emphasize the role of religious beliefs, practices, and social networks in shaping these efforts.

Religious beliefs were often a precursor to individuals' decisions to rescue, when their lives were at risk. The belief that they were doing right by God assured them that if they died while saving others, they would be rewarded in the afterlife, thus providing a cognitive safety net. Previous studies of high-risk actions have demonstrated the correlation between religious beliefs in an afterlife and low death anxiety. ${ }^{87}$ We argue that respondents in this study who rescued were enabled in part by a low death anxiety. Generally, they believed that the high risks they took to save others were part of God's plan, and if they died saving others, they would go to heaven. As such, these beliefs diminished the perception of risk; if the choice was between betraying God by doing nothing or dying while doing right by God, these religious individuals considered the latter to be the less risky of the two choices and acted accordingly. Future studies would benefit from comparing the death anxiety of those who solely rescued with the death anxiety among those who killed and also rescued.

Religious practices also served as social buffers from intense recruitment to genocidal violence and from being discovered once they were hiding people. Again, we illustrate how this specific factor was highly gendered, and future studies should address whether religion provided a social buffer for women who rescued. Better understanding how religious practices create social buffers enabling individuals to rescue others may also be beneficial in developing strategies for violence mitigation efforts.

Finally, religious social networks also shaped rescue efforts, including where these efforts took place, how they unfolded, and who they impacted. Scholars have previously documented that religious social networks provide exchanges of resources and care, 88 and we extend this line of work to the context of rescue. For instance, many of our respondents hid Tutsi in churches and mosques, illustrating the importance of the resources provided by religious social networks for rescue efforts. Furthermore, our respondents relied on fellow congregants within their religious social networks to assist them in their efforts to save friends, family, and even strangers. We also saw some evidence that religious social networks facilitated who was rescued, as respondents discussed rescuing people they knew from their churches and mosques.

To be clear, religious beliefs, practices, and social networks are not mutually exclusive factors and certainly impact one another. These pathways may have also affected rescue efforts in ways we could not demonstrate here. For instance, in addition to beliefs, religious social networks may have impacted decisions to rescue. It is plausible that simply knowing that one has a strong religious social network might make rescue feel more achievable, or observing others in one's religious community rescuing might influence one's decision to engage in such efforts. While it is difficult to ascertain the factors that impacted individuals' initial decisions to rescue with retrospective data, we have focused on the key factors that emerged from our interviews.

\footnotetext{
85 Interviewee first cited in note 69.

86 Pseudonym, Male, Age 31 at the time of rescue, Pentecostal, 2019, Rwanda.

87 Silton et al., Association Between Religious Beliefs, 366.

88 Corwin E. Smidt, ed., Religion as Social Capital: Producing the Common Good (Waco: Baylor University Press, 2003), 14.
} 
In this case, religious beliefs about God's plan and the afterlife created cognitive safety nets to enable high-risk action; religious practices socially buffered individuals who rescued from those committing violence, helping them escape recruitment and discovery; and religious social networks supplied shelter, exchanges of information, medical care, and food to keep families, children, and congregants alive. Hundreds of people are alive today because of the actions of these 45 respondents. These respondents teach us that religion-through beliefs, practices, and social networks - has the power to make high-risk actions feel possible, to buffer against violence, and to facilitate coordinated collective action that saves lives.

\section{Bibliography}

Baier, Colin J. and Bradly R. E. Wright. "'If You Love Me, Keep My Commandments:' A MetaAnalysis of the Effect of Religion on Crime." Journal of Research in Crime and Delinquency 38, no. 1 (2001), 3-21.

Barrett, Jennifer B., Julie Da Vanzo, Christopher G. Ellison, and Clifford Grammich. "Religion and Attitudes Toward Family Planning Issues Among US Adults." Review of Religious Research 56, no. 2 (2014), 161-188.

Begley, Larissa R. "The Other Side of Fieldwork: Experiences and Challenges of Conducting Research in the Border Area of Rwanda/Eastern Congo." Anthropology Matters 11, no. 2 (2009), 1-11.

Block, Gay and Malka Drucker, eds. Rescuers: Portraits of Moral Courage in the Holocaust. New York: Lynne Rienner Publishers, 1992.

Braun, Robert. Protectors of Pluralism: Religious Minorities and the Rescue of Jews in the Low Countries During the Holocaust. Cambridge: Cambridge University Press, 2019.

Burnet, Jennie E. "Accountability for Mass Death, Acts of Rescue, and Silence in Rwanda." In A Companion to the Anthropology of Death, edited by Antonius C. G. M. Robben, 205-221. Hoboken: John Wiley \& Sons, Inc., 2018.

Casiro, Jessica. "Argentine Rescuers: A Study on the 'Banality of Good.'” Journal of Genocide Research 8, no. 4 (2006), 437-454.

Constantine, Madonna G., Marie L. Miville, Anika K. Warren, Kathy A. Gainor, and Ma'at E. L. Lewis-Coles. "Religion, Spirituality, and Career Development in African American College Students: A Qualitative Inquiry." The Career Development Quarterly 54, no. 3 (2011), 227-241.

Des Forges, Alison. Leave None to Tell the Story: Genocide in Rwanda. New York: Human Rights Watch, 1999, 1-537. Accessed April 20, 2021. https:/ / www.hrw.org/sites/default/files/ media 2020/12/rwanda-leave-none-to-tell-the-story.pdf.

Dilulio Jr., John D. "More Religion, Less Crime? Science, Felonies, and the Three Faith Factors." Annual Review of Law and Social Science 5, no.1 (2009), 115-133.

Durkheim, Emile. Suicide. New York: Free Press, [1897] 1966.

Eichler-Levine, Jodi and Rosemary Hicks. "As Americans against Genocide: The Crisis in Darfur and Interreligious Political Activism." American Quarterly 59, no. 3 (2007), 711735.

Einolf, Christopher J. "The Link Between Religion and Helping Others: The Role of Values, Ideas, and Language." Sociology of Religion 72, no. 4 (2011), 435-455.

Eitle, David. "Religion and Gambling Among Young Adults in the United States: Moral Communities and the Deterrence Hypothesis." Journal for the Scientific Study of Religion 50, no. 1 (2011), 61-81.

Ellison, Christopher G. and Michael J. McFarland. "Religion and Gambling Among U.S. Adults: Exploring the Role of Traditions, Beliefs, Practices, and Networks." Journal for the Scientific Study of Religion 50, no. 1 (2011), 82-102.

Fagin-Jones, Stephanie. "Holocaust Heroes: Heroic Altruism of Non-Jewish Moral Exemplars in Nazi Europe." In Handbook of Heroism and Heroic Leadership, edited by Scott T. Allison, George R. Goethals, and Roderick M. Kramer, 203-228. New York: Routledge, 2016. 
Fagin-Jones, Stephanie and Elizabeth Midlarsky. "Courageous Altruism: Personal and Situational Correlates of Rescue During the Holocaust." The Journal of Positive Psychology 2, no. 2 (2007), 136-147.

Fastnow, Chris J., Tobin Grant, and Thomas J. Rudolph. "Holy Roll Calls: Religious Tradition and Voting Behavior in the U.S. House." Social Science Quarterly 80, no. 4 (1999), 687701.

Fitzgerald, Maureen. Habits of Compassion: Irish Catholic Nuns and the Origins of New York's Welfare System, 1830-1920. Champaign: University of Illinois Press, 2006.

Fleischner, Eva. "Remembrance and Responsibility: Rescuers of Jews During the Shoah." In Good and Evil After Auschwitz: Ethical Implications for Today, edited by Jack Bemporad, John T. Pawlikowski, and Joseph Sievers, 203-213. Hoboken: KTAV Publishing House, 2000.

Fogelman, Eva. "The Rescuer Self." In The Holocaust and History: The Known, the Unknown, the Disputed, and the Reexamined, edited by Michael Berenbaum and Abraham J. Peck, 663677. Bloomington: Indiana University Press, 1998.

Fox, Nicole and Hollie Nyseth Brehm. "'I Decided to Save Them:' Factors that Shaped Participation in Rescue Efforts During the Genocide in Rwanda." Social Forces 96, no. 4 (2018), 1625-1647.

Frisk, Kristian. "What Makes a Hero? Theorising the Social Structuring of Heroism." Sociology 53, no. 1 (2019), 87-103.

Fujii, Lee Ann. Killing of Neighbors: Webs of Violence in Rwanda. Ithaca: Cornell University Press, 2009.

Garner, Robert C. "Safe Sects? Dynamic Religion and AIDS in South Africa." The Journal of Modern African Studies 38, no. 1 (2000), 41-69.

Gross, Michael L. "Jewish Rescue in Holland and France during the Second World War: Moral Cognition and Collective Action." Social Forces 73, no. 2 (1994), 463-496.

Guichaoua, André. From War to Genocide: Criminal Politics in Rwanda, 1990-1994. Madison: University of Wisconsin Press, 2015.

Gushee, David P. "Many Paths to Righteousness: An Assessment of Research on Why Righteous Gentiles Helped Jews." Holocaust and Genocide Studies 7, no. 3 (1993), 372-401.

. "Rescuers: Their Motives and Morals." In The Holocaust and the Christian World: Reflections on the Past, Challenges for the Future, edited by Carol Rittner, Stephen D. Smith, and Irena Steinfeldt, 159-161. London: Beth Shalom Holocaust Memorial and Education Center, 2000.

Harding, Stephen R., Kevin J. Flannelly, Andrew J. Weaver, and Karen G. Costa. “The Influence of Religion on Death Anxiety and Death Acceptance." Mental Health, Religion \& Culture 8, no. 4 (2005), 253-261.

Hernandez, Esperanza F., Pamela F. Foley, and Ben K. Beitin. "Hearing the Call: A Phenomenological Study of Religion in Career Choice." Journal of Career Development 38, no. 1 (2010), 62-88.

Hoffman, Mitchell. "Does Higher Income Make You More Altruistic? Evidence from the Holocaust." The Review of Economics and Statistics 93, no. 3 (2011), 876-887.

Hutchinson, Elizabeth D. "Spirituality, Religion, and Progressive Social Movements: Resources and Motivation for Social Change." Journal of Religion \& Spirituality in Social Work: Social Thought 3, no. 1-2 (2012), 105-127.

Ingelaere, Bert. "Learning 'To Be' Kinyarwanda in Postgenocide Rwanda: Immersion, Iteration, and Reflexivity in Times of Transition." Canadian Journal of Law and Society 30, no. 2 (2015), 277-292.

Jessee, Erin. "Conducting Fieldwork in Rwanda." Canadian Journal of Development 33, no. 2 (2012), 266-274.

Johnson, Byron R., Sung Joon Jang, David B. Larson, and Spencer De Li. “Does Adolescent Religious Commitment Matter? A Reexamination of the Effects of Religiosity on Delinquency." Journal of Research in Crime and Delinquency 38, no. 1 (2001), 22-44. 
Johnson, Byron, Sung Joon Jang, Spencer De Li, and David Larson. “The 'Invisible Institution' and Black Youth Crime: The Church as an Agency of Local Social Control." Journal of Youth and Adolescence 29 (2000), 479-498.

Lichterman, Paul. "Religion in Public Action: From Actors to Settings." Sociological Theory 30, no. 1 (2012), 15-36.

Longman, Timothy. Christianity and Genocide in Rwanda. Cambridge: Cambridge University Press, 2009.

. "Church Politics and the Genocide in Rwanda." Journal of Religion in Africa 31, no. 2 (2001), 163-186.

Luft, Aliza. "Toward a Dynamic Theory of Action at the Micro-Level of Genocide: Killing, Desistance, and Saving in 1994 Rwanda." Sociological Theory 33, no. 2 (2015), 148-172.

Mamdani, Mahmood. When Victims Become Killers: Colonialism, Nativism, and the Genocide in Rwanda. Princeton: Princeton University Press, 2001.

McAdam, Doug. "Recruitment to High-Risk Activism: The Case of Freedom Summer." American Journal of Sociology 92, no. 1 (1986), 64-90.

Minnesota Population Center. Integrated Public Use Microdata Series, International: Version 7.2 [dataset]. Minneapolis, MN: IPUMS, 2019. Accessed April 20, 2021. https://doi.org/ 10.18128/D020.V7.2.

Nelson, L. D. and C. H. Cantrell. "Religiosity and Death Anxiety: A Multi-Dimensional Analysis." Review of Religious Research 21, no. 2 (1980), 148-157.

Oliner, Pearl M., Jeanne Wielgus, and Mary B. Gruber. "Very Religious and Irreligious Rescuers." In Remembering for the Future: The Holocaust in an Age of Genocide, edited by John K. Roth, Elisabeth Maxwell, Margot Levy, and Wendy Whitworth, 1235-1244. London: Palgrave Macmillan, 2001.

Oliner, Samuel P. and Pearl M. Oliner. The Altruistic Personality: Rescuers of Jews in Nazi Europe. New York: The Free Press, 1992.

Park, Jerry Z. and Christian Smith. “'To Whom Much Has Been Given...:' Religious Capital and Community Voluntarism among Churchgoing Protestants." Journal for the Scientific Study of Religion 39, no. 3 (2000), 272-286.

Pettersson, Thorleif. "Religion and Criminality: Structural Relationships Between Church Involvement and Crime Rates in Contemporary Sweden." Journal for the Scientific Study of Religion 30, no. 3 (1991), 279-291.

Pichon Isabelle and Vassilis Saroglou. "Religion and Helping: Impact of Target Thinking Styles and Just-World Beliefs." Psychology of Religion 31, no. 2 (2009), 215-236.

Purdeková, Andrea. "'Even If I Am Not Here, There Are So Many Eyes:' Surveillance and State Reach in Rwanda." The Journal of Modern African Studies 49, no. 3 (2011), 475-497.

Rothbart, Daniel and Jessica Cooley. "Hutus Aiding Tutsis during the Rwandan Genocide: Motives, Meanings, and Morals." Genocide Studies and Prevention: An International Journal 10, no. 2 (2016), 76-97.

Schieman, Scott. "Education and the Importance of Religion in Decision Making: Do Other Dimensions of Religiousness Matter?." Journal for the Scientific Study of Religion 50, no. 3 (2011), 570-587.

Schultz, Debra. Going South: Jewish Women in the Civil Rights Movement. New York: New York University Press, 2001.

Shariff, Azim F. and Ara Norenzayan. "Mean Gods Make Good People: Different Views of God Predict Cheating Behavior." The International Journal for the Psychology of Religion 21, no. 2 (2011), 85-96.

Sigalow, Emily, Michelle Stain, and Meredith R. Bergey. "Religion and Decisions About Marriage, Residence, Occupation, and Children." Journal for the Scientific Study of Religion 51, no. 2 (2012), 304-323.

Silton, Nava, Kevin J. Flannelly, Christopher G. Ellison, Kathleen Galek, Martha R. Jacobs, John P. Marcum, and Faye J. Silton. "The Association Between Religious Beliefs and Practices 
and End-of-Life Fears Among Members of the Presbyterian Church (U.S.A.)." Review of Religious Research 53, no. 1 (2011), 357-370.

Smidt, Corwin E., ed. Religion as Social Capital: Producing the Common Good. Waco: Baylor University Press, 2003.

Staub, Ervin. "The Psychology of Bystanders, Perpetrators, and Heroic Helpers." International Journal of Intercultural Relations 17, no. 3 (1993), 315-341.

Straus, Scott. The Order of Genocide: Race, Power, and War in Rwanda. Ithaca: Cornell University Press, 2006.

Tec, Nechama. When Light Pierced the Darkness: Christian Rescue of Jews in Nazi-Occupied Poland. Oxford: Oxford University Press, 1986.

Thomson, Susan. Whispering Truth to Power: Everyday Resistance to Reconciliation in Postgenocide Rwanda. Madison: University of Wisconsin Press, 2013.

Ulmer, Jeffery T. and Casey T. Harris. "Race and the Religious Contexts of Violence: Linking Religion and White, Black, and Latino Violent Crime." Sociological Quarterly 54, no. 4 (2013), 610-646.

Van Cappellen, Patty, Vassilis Saroglou, and Maria Toth-Gauthier. "Religiosity and Prosocial Behavior Among Churchgoers: Exploring Underlying Mechanisms." The International Journal for the Psychology of Religion 26, no. 1 (2016), 19-30.

Varese, Federico and Meir Yaish. "The Importance of Being Asked: The Rescue of Jews in Nazi Europe." Rationality and Society 12, no. 3 (2000), 307-334.

Wasserman, Ira and Frank Trovato. "The Influence of Religion on Smoking and Alcohol Consumption: Alberta Case Study." International Review of Modern Sociology 26, no. 2 (1996), 43-56. 